\title{
Improved Functional Characteristics of Whey Protein Hydrolysates in Food Industry
}

\author{
Renda Kankanamge Chaturika Jeewanthi ${ }^{1, \dagger}$, Na-Kyoung Lee ${ }^{1, \dagger}$, and Hyun-Dong Paik ${ }^{1,2, *}$ \\ ${ }^{1}$ Department of Food Science and Biotechnology of Animal Resources, Konkuk University, Seoul 143-701, Korea \\ ${ }^{2}$ Bio/Molecular Informatics Center, Konkuk University, Seoul 143-701, Korea
}

\begin{abstract}
This review focuses on the enhanced functional characteristics of enzymatic hydrolysates of whey proteins (WPHs) in food applications compared to intact whey proteins (WPs). WPs are applied in foods as whey protein concentrates (WPCs), whey protein isolates (WPIs), and WPHs. WPs are byproducts of cheese production, used in a wide range of food applications due to their nutritional validity, functional activities, and cost effectiveness. Enzymatic hydrolysis yields improved functional and nutritional benefits in contrast to heat denaturation or native applications. WPHs improve solubility over a wide range of $\mathrm{pH}$, create viscosity through water binding, and promote cohesion, adhesion, and elasticity. WPHs form stronger but more flexible edible films than WPC or WPI. WPHs enhance emulsification, bind fat, and facilitate whipping, compared to intact WPs. Extensive hydrolyzed WPHs with proper heat applications are the best emulsifiers and addition of polysaccharides improves the emulsification ability of WPHs. Also, WPHs improve the sensorial properties like color, flavor, and texture but impart a bitter taste in case where extensive hydrolysis (degree of hydrolysis greater than $8 \%$ ). It is important to consider the type of enzyme, hydrolysis conditions, and WPHs production method based on the nature of food application.
\end{abstract}

Keywords: whey protein, whey protein hydrolysate, enzymatic hydrolysis, functionality, food application

Received February 3, 2015; Revised April 6, 2015; Accepted April 27, 2015

\section{Introduction}

Whey protein (WP) is now recognized as a value-added ingredient because of its highly functional and nutritional properties. WPs are used widely by dairies, bakeries, confectionaries, meat processing plants, canned goods, and beverage establishments for their various functions in food quality and stability (de Wit, 1998; Foegeding et al., 2002). Because of their nutritional and functional properties, researchers have intensified efforts to expand the utilization of WPs as food ingredients. Technological advances have enabled researchers to enhance the functionality and utilization of WP by producing more concentrated and specialized forms. Pressure-driven membrane processes have been used to concentrate and separate whey protein concentrates (WPCs) or whey protein isolates (WPIs) in order to maintain their functional properties

\footnotetext{
${ }^{\dagger}$ These authors contributed equally to this work.

*Corresponding author: Hyun-Dong Paik, Department of Food Science and Biotechnology of Animal Resources, Konkuk University, Seoul 143-701, Korea. Tel: +82-2-2049-6011, Fax: +822-455-3082, E-mail: hdpaik@konkuk.ac.kr
}

and make them suitable for other purposes in the food industry (Suarez et al., 1992). Today, WP ingredients are used to replace other proteins or to improve the functional properties of many food products (Spellman et al., 2005).

WPs are comprised mainly of $\beta$-lactoglobulin $(\beta-\mathrm{Lg})$, $\alpha$-lactalbumin $(\alpha-\mathrm{La})$, bovine serum albumin (BSA), and immunoglobulin, and the effects of WP functionality have been studied extensively (Foegeding et al., 2002; Smithers et al., 2008). $\beta$-Lg, a globular and amphiphilic protein with two disulfides and one free cysteine, is the main constituent of WP (around 55\% of proteins) and is known to contribute the most to the WP functionality (Bouaouina et al., 2006). Conformation and functionality of WPs are interrelated and dictated by changes in their globular folded structure. Their functional properties are affected by several factors within a food application, including concentration, state of the WPs, $\mathrm{pH}$, ionic environment, (pre-) heat treatment, pressure treatments, and the presence of lipids (Burrington, 1999). The functionality of WPs can be improved by chemical, enzymatic, and physical processes. High pressure treatments are used to enhance the functionality of WPC, but still remain below the expected levels of the industrial food applications (Kresic et al., 
2006). Enzymatic modifications are highly acceptable and applied in the industry not only for functionality improvement but also for bioactive enhancement (Athira et al., 2014; Sharma et al., 2011). These hydrolysates are also being used as protein supplements for infants, senescent, athletes, and bodybuilders (Sousa et al., 2004). The resulting peptides are more easily absorbed but the level of hydrolysis has to be carefully controlled to avoid the formation of bitter peptides (Mann, 2000).

Enzymatic hydrolysis is preferred by food manufacturers due to the availability of a wide range of enzymes that are considered safe and natural. Several enzymes are currently used in the industry as food-grade enzymes and others are being researched for the production of WPHs with tailored functionality and biological activity. The most researched and used enzymes for the production of WPHs are the digestive enzymes trypsin, pepsin, and chymotrypsin (Konrad et al., 2005; Pouliot et al., 2009), plant enzymes mainly papain and bromelain (Nakamura et al., 1993), bacterial proteases mainly those originating from Bacillus licheniformis (Creusot et al., 2006; Creusot and Gruppen, 2007a, 2007b; Doucet and Foegeding, 2005) and Bacillus subtilis (Madsen et al., 1997), or a mixture of some of these enzymes (Kim et al., 2007). The objective of this review is to emphasize the improvement in functional characteristics of WPHs over those of intact WPs in food applications.

\section{Manufacture of Whey Protein Products}

\section{Whey protein concentrates (WPCs) and whey pro- tein isolates (WPIs)}

The most valuable component of whey is its protein, which delivers both enhanced functionality and nutritional quality to many formulations. WPs are able to concen- trate, fracture, and dehydrate efficiently and cost-effectively without damaging the protein structure (Fig. 1). By these methods WPs are produced and introduced to the market as whey protein concentrates (WPCs, 35-80\% protein) and whey protein isolates (WPIs, $90-96 \%$ protein).

\section{Whey protein hydrolysates (WPHs)}

Two main methods of improving WP functionality are modification of proteins through physical treatments, and enzymatic means. Chemical modifications of proteins are possible but due to the necessity to prove the safety of such modifications to humans, they are not generally practiced. Chemical hydrolysis causes loss of some essential amino acids, such as tryptophan, and can result in products with high amounts of free amino acids, which can encumber the body's osmotic balance (Mahmoud, 1994).

For WPs hydrolyzing, enzymatic hydrolysis is the most applicable method in food industry. The functional and biological properties of the WPHs depend to a great extent on the type of enzyme used (specificity and selectivity), hydrolysis conditions (enzyme-to-substrate ratio, incubation temperature, $\mathrm{pH}$, and time) employed, and the source of the protein, native or denatured, WPI vs. WPC, membrane or ion-exchange product, etc. Researchers have shown that limited enzymatic hydrolysis of WPs can result in markedly improved functionality and biological activities (Creusot and Gruppen, 2008; Pouliot et al., 2009; Spellman et al., 2009).

\section{Functional benefits}

WPs have typically a globular structure, with high levels of secondary and tertiary structures, in which acidic/ basic and hydrophobic/hydrophilic amino acids are distributed in polypeptide chains. The functional benefits depend on (a) hydration, (b) aggregation and gelation, (c)

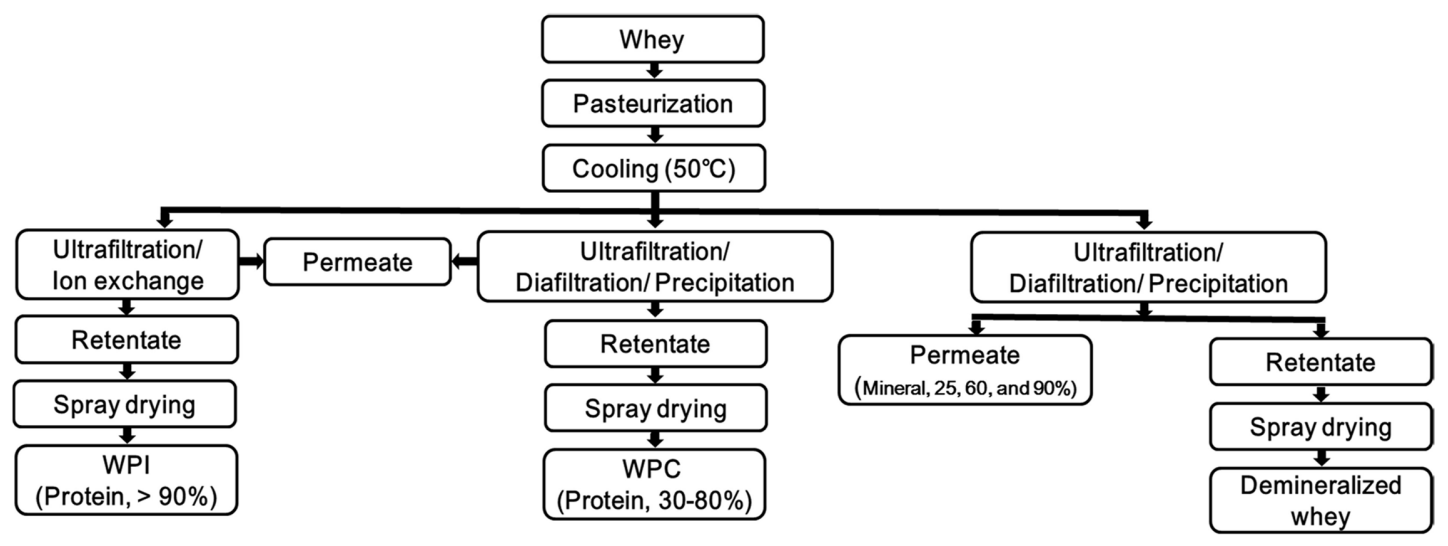

Fig. 1. Production steps of whey products. 


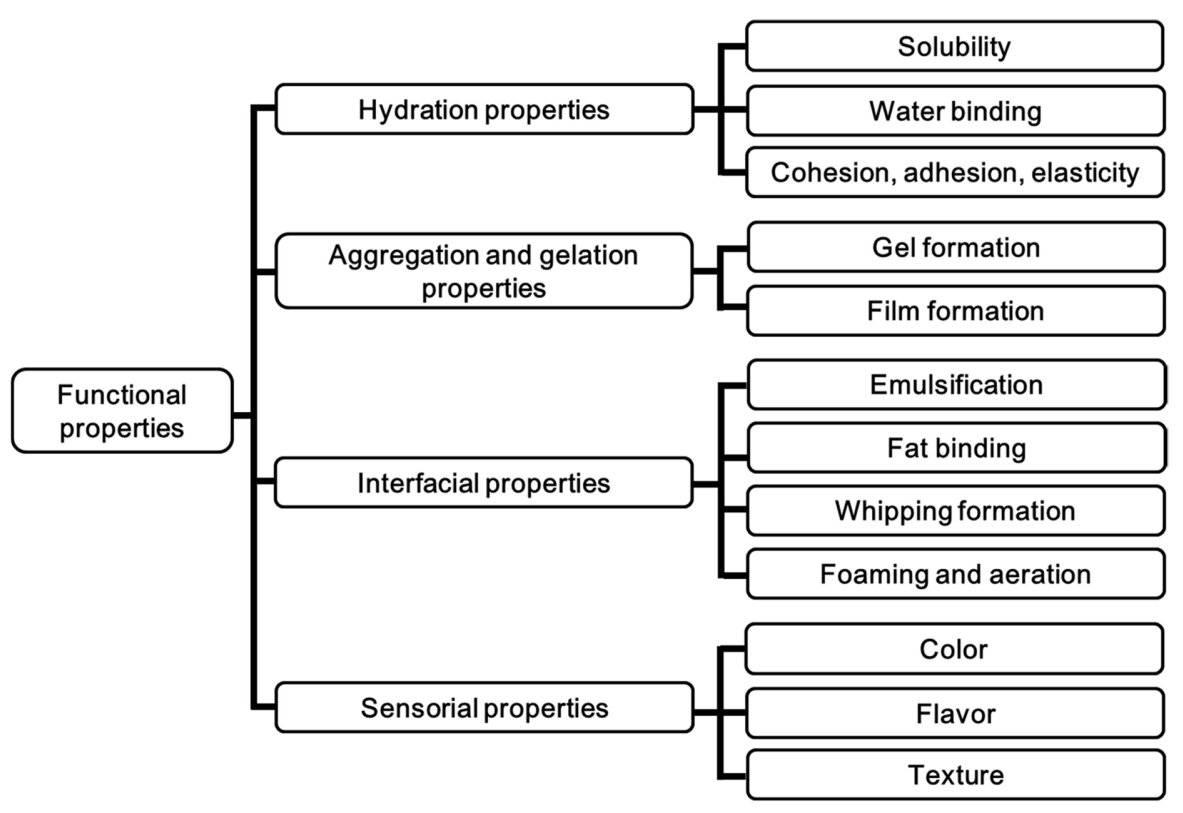

Fig. 2. Classification of functional properties of WPHs in food applications.

interfacial, and (d) sensorial properties of the food protein (Fig. 2) (Kresic et al., 2006). Hydration properties have an important effect on swelling, adhesion, dispersibility, solubility, viscosity, water absorption, and water holding. Aggregation and gelation properties, on the other hand are related to protein-protein interactions while Interfacial properties include emulsification and foaming characteristics. Sensorial properties include flavor, color, and texture properties of the protein.

\section{Hydration properties}

\section{Solubility}

The solubility of WPCs at a low $\mathrm{pH}$ is a unique property that allows it to function in acidic foods and beverages (Kumar et al., 2010; Pelegrine and Gasparetto, 2005). It has a great potential as a food ingredient for the protein enrichment of soft drinks and beverages. Heating WPs can result in a loss of solubility due to the denaturation of the proteins, especially in the $\mathrm{pH}$ range of 4.0-6.5 (Burrington, 1999). Most foods are heat processed in some way, and WPs are susceptible to changes during heating. Denaturation at low $\mathrm{pH}$ leads to aggregation and insolubility. One challenge for WP is maintaining solubility during heat processing. Solubility of WPCs decreases as temperature increases (Pelegrine and Gomes, 2012). However, the maximum intermolecular aggregation of $\beta$-Lg without heat does occur near the iso-electric point due to neutralization of charges and interaction via hydrophobic forces (Majhi et al., 2006; Mehalebi et al., 2008; Schmitt et al., 2009). Increasing the ionic strength results in salting in of $\beta-\operatorname{Lg}$ (Majhi et al., 2006).

In many cases, limited hydrolysis leads to increased solubility due to the reduced molecular weight and the increased hydrophilicity resulting from the increase in free carboxyl and amine groups. Researchers proposed that hydrolyzing WPs with various proteolytic enzymes under different conditions can be used to improve the solubility over a wide range of $\mathrm{pH}$ (Mutilangi et al., 1996; Perea et al., 1993). WPHs had shown less solubility in $\mathrm{pH}$ 4 while showing the highest solubility around $\mathrm{pH}$ 6-10 (Jeewanthi et al., 2014). More extensive hydrolysis has been shown to increase solubility (Flanagan and Fitzgerald, 2002; Jeewanthi et al., 2014). Also, heat stability was improved upon partial hydrolysis due to loss of the secondary structure, thus contributing to reduced structural changes upon heating (Foegeding et al., 2002).

Adhesion, cohesion, elasticity, and water-binding The adhesion properties of WPCs help to improve the homogeneous texture of food products. WPCs may be used to bind breadcrumbs or batter to meat, poultry or fish. Effective adhesion between meat pieces is an important quality characteristic in the manufacture of products such as chicken nuggets or restructured ham. The actual meat particle binding occurs during cooking as heat setting of the proteins takes place. WPs aid in this binding by forming strong, irreversible gels that restructure into 
an extended three-dimensional network, thereby helping to adhesion (Prabhu, 2006). WPCs decreased the average hardness and chewiness values and increased cohesiveness of the sausages. The adhesion of the WPs is affected by temperature due to denaturation of protein structure (Goode et al., 2013).

Moisture binding is especially important during the cooking stage when the denaturing salt soluble meat proteins experience a progressive decline in water holding capacity (Tsai et al., 1998). Barbut (2007) reported that poultry treated with WPHs had the lowest cooking loss and highest yield with higher water retention capacity compared to those treated with WPI, casinate, $\beta-\mathrm{Lg}$, and whole milk proteins. The water-binding abilities of WPs can help reduce formula costs as the proteins holds additional water. Viscosity development is closely related to gelation and other protein-protein interactions (Burrington, 1999).

\section{Aggregation and gelation properties}

\section{Gel formation}

Gelation is an important functionality that is useful in baked goods, processed meats, surimi, desserts, and sour cream. A gel is an intermediate structure between solid and liquid, which carbohydrates or protein strands crosslink to form a network. Gelation is favored by large molecules of proteins since they form extensive networks by cross-linking in three dimensions and by the ability of the denaturing. Rinn et al. (1990) reported that WPCs prepared by microfiltration through $0.6 \mu \mathrm{m}$ pores exhibited superior gels at $4-5 \%$ protein. In restructuring new meat products, WPCs have been utilized for their abilities to exhibit heat-coagulating and heat gelling properties (Morr and Ha, 1993). Cold-set gelation of WPs has also been noted by Bryant and McClements (1998). Hydrolyzed â$\mathrm{Lg}$ also has the ability to form networks associated with gels (Foegeding et al., 2002).

In their un-denatured form, WPs form rigid gels that hold water and fat, and provide structural support. The formation of disulfide bonds and ionic bonding controlled by calcium ions determine gel structure (Burrington, 1999). Hydrophobic interactions can play a major role in partially hydrolyzed proteins and consequently unfolding the protein structure (Pinterits and Arnteld, 2007). This exposes buried hydrophobic groups and other interactive groups which are then free to interact with neighboring polypeptides (Kang et al., 1994). This promotes protein aggregations and subsequent gel setting. The effect of hydrolysis on the gelation ability of WP is dependent on environmental conditions and on the degree of hydrolysis (DH). On the other hand, extensive hydrolysis of WPI can weaken its gelation properties (Huang et al., 1999). Non heat-set gelation forms strong elastic gels during extensive hydrolysis of WPI at high solid content $(20 \% \mathrm{w} / \mathrm{v})$ with Alcalase 2.4L, a protease from Bacillus licheniformis (BLP) than the heat induced gels (Doucet et al., 2001). Among the enzymes investigated for the production of WPH with enhanced gelation properties, BLP is well studied (Creusot et al., 2006; Creusot and Gruppen, 2007a, 2007b; Creusot and Gruppen, 2008; Doucet and Foegeding, 2005; Spellman et al., 2005). Further, Spellman et al. (2005) showed, after isolating subtilisin and glutamyl endopeptidase (GE) activities from Alcalase 2.4L, that the $\mathrm{GE}$ is the enzyme responsible for the peptide aggregation in WPHs. With enzymatic hydrolysis performing under different conditions, researchers were able to produce gels with different rheological properties (Table 1). The increased net charge on proteins results in increased repulsion between peptides. Interestingly, limited proteolysis with enzymes can also be used to control the gelling ability as well as the gel strength.

Trypsin also showed gelation properties after hydrolysis of WPs. Tryptic hydrolysis of WPs at 6.7 and $2.3 \%$ $\mathrm{DH}$ prevented gelation at $\mathrm{pH} 3$ and 7, whereas hydrolysis to $2.3 \% \mathrm{DH}$ with BLP dramatically increased the gelling ability and gel strength at neutral pH (Ju et al., 1995). The aggregates formed upon hydrolysis of $\beta-\mathrm{Lg}$ by BLP consisted of 6-7 major peptides (2-6 kDa) (Otte et al., 1996b). Peptides from $\beta$-Lg formed aggregates with other peptides and with intact $\beta$-Lg and $\alpha$-La via hydrophobic interactions leading to gelation. Some researchers have found the key fragments that act as the initiators of aggregation of WPHs (Table 2).

\section{Film formation}

In food systems, edible, and permeable film coatings are used to control the transfer of aroma, flavor compounds, moisture, oxygen, and lipid. WP has been shown to make transparent films with good oxygen and aroma barrier properties (Mate and Krochta, 1996; Miller et al., 1997). McHugh et al. (1994) produced WPCs films by heating $8-12 \%(\mathrm{w} / \mathrm{w})$ solutions of $\mathrm{WPC}$ at $75-100^{\circ} \mathrm{C}$. The suggested optimal condition for producing these films is to heat $10 \% \mathrm{WPC}$ solutions at $90^{\circ} \mathrm{C}$. Exposure of internal S$\mathrm{H}$ and hydrophobic groups after denaturation by heating of WPs support improved film formation. The intramolecular S-S bonds of heat denatured WP films form insoluble 
Table 1. Different gel characteristics resulting from whey protein hydrolysates made with BLP under several conditions

\begin{tabular}{|c|c|c|c|c|}
\hline "Gelation characteristics & Enzyme & Whey product & Hydrolytic condition & Reference \\
\hline Very high gelation & $\begin{array}{c}\text { Subtilisin Carlsberg }+ \\
\text { Glutamil endopeptidase } \\
\text { (Alcalase } 2.4 \mathrm{~L} \text { ) }\end{array}$ & Hydrolysates of WPC $80 \%$ & $\begin{aligned} & 50^{\circ} \mathrm{C} \\
> & 0.4 \mathrm{DH} \\
& \mathrm{pH} 7\end{aligned}$ & Spellman et al., 2005 \\
\hline Gelation & BLP(aq) $2 \%(w / w)$ & Hydrolysates of WPI & Limited or Extensive & $\begin{array}{l}\text { Creusot and Gruppen, } \\
2007 \mathrm{a}\end{array}$ \\
\hline Gelation & BLP(aq) $2 \%(w / w)$ & Hydrolysates of WPI & $\begin{array}{c}4^{\circ} \mathrm{C} \\
\text { Extensive }\end{array}$ & Creusot et al., 2006 \\
\hline Strong gelation & BLP & Hydrolysates of WPC & $\begin{array}{c}\text { Salt/polysaccharide } \\
\text { added }\end{array}$ & Rocha et al., 2009 \\
\hline Strong and faster gelation & BLP & Hydrolysates of WPI & Below pH 6.2 & Ipsen et al., 1997 \\
\hline Translucent strong gelation & BLP & Hydrolysates of WPI & Limited & Otte et al., 1999 \\
\hline Cold gelation & BLP & Hydrolysates of WPI & $\begin{array}{l}\text { Salt added/ } \\
\text { acidification }\end{array}$ & $\begin{array}{l}\text { Rabiey and Britten, } \\
\text { 2009a } \\
\text { Rabiey and Britten, } \\
2009 \mathrm{~b}\end{array}$ \\
\hline Soft gelation & BLP & Hydrolysates of WPI & $\begin{array}{l}\text { Limited } \\
\text { DH } 2.2 \%\end{array}$ & Otte et al., 1996a \\
\hline $\begin{array}{l}\text { White, soft, and } \\
\text { thixotropic gelation }\end{array}$ & BLP & Hydrolysates of WPI & $\begin{array}{c}45^{\circ} \mathrm{C} \\
1 \mathrm{~h} \text { hydrolysis }\end{array}$ & Ju and Kilara, 1998 \\
\hline $\begin{array}{c}\text { Stable gelation } \\
\text { over wide } \mathrm{pH} \text { range }\end{array}$ & Subtilisin Carlsberg & Hydrolysates of WPI & Extensive & $\begin{array}{l}\text { Doucet et al., 2003a } \\
\text { Doucet et al., 2003b }\end{array}$ \\
\hline Thin strong gelation & BLP & $\begin{array}{l}\text { Hydrolysates of WPI } \\
\text { (heat induced) }\end{array}$ & pH 7 & Ju et al., 1995 \\
\hline Strong elastic gelation & Alcalase $2.4 \mathrm{~L}$ & Hydrolysates of WPI & Extensive & Doucet et al., 2001 \\
\hline
\end{tabular}

BLP, protease from Bacillus licheniformis; DH, degree of hydrolysis.

Table 2. Key peptides of gelation properties in different types of whey protein hydrolysates

\begin{tabular}{|c|c|c|c|c|}
\hline Whey product & Enzyme & $\begin{array}{l}\text { Hydrolysis } \\
\text { condition }\end{array}$ & Peptides & Reference \\
\hline Hydrolysates of WPI & Alcalase & Limited & $\beta-\operatorname{Lg}[\mathrm{f} 135-158]$ & $\begin{array}{c}\text { Doucet and Foegeding, } \\
2005\end{array}$ \\
\hline Hydrolysates of WPI & $\operatorname{BLP}(\mathrm{aq})$ & $\begin{array}{l}\text { DH } 6.8 \% \\
\text { pH } 7\end{array}$ & 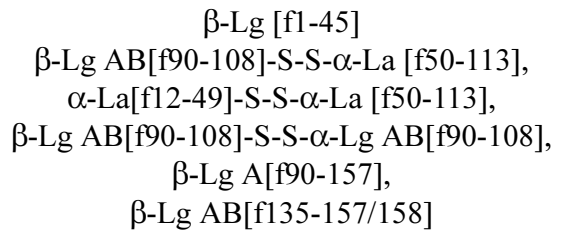 & $\begin{array}{l}\text { Creusot and Gruppen, } \\
\qquad 2007 \mathrm{~b}\end{array}$ \\
\hline Hydrolysates of WPI & $\begin{array}{l}\text { BLP (glutamyl } \\
\text { endopeptidase) }\end{array}$ & $\mathrm{pH} 8$ & Peptides of $\beta$-Lg and $\alpha$-La & Ipsen et al., 2000 \\
\hline Hydrolysates of $\beta$-Lg & Trypsin & $\begin{array}{l}5-50^{\circ} \mathrm{C} \\
\mathrm{pH} 4\end{array}$ & $\beta-\operatorname{Lg}[\mathrm{f} 1-8], \beta-\operatorname{Lg}[\mathrm{f} 15-20], \beta-\operatorname{Lg}[\mathrm{f} 41-60]$ & $\begin{array}{l}\text { Groleau et al., 2003a } \\
\text { Groleau et al., 2003b }\end{array}$ \\
\hline Hydrolysates of WPI & Trypsin & $>$ pH 2 & $\beta-\operatorname{Lg}[\mathrm{f} 1-8]$ & Pouliot et al., 2009 \\
\hline
\end{tabular}

BLP, protease from Bacillus licheniformis; $\beta$-Lg, $\beta$-lactoglobulin; $\alpha$-La, $\alpha$-lactalbumin; $\mathrm{DH}$, degree of hydrolysis.

films while native proteins form soluble films (PerezGago and Krochta, 2002). Various measures have been studied to improve barrier capacity and mechanical strength of WPC films. Due to protein chain-to-chain interactions, films with high brittleness are created.

To overcome this and improve the flexibility of the films, hydrolysis of WP provided a much better approach than the addition of plasticizers. Hydrolysates improve the film tensile properties and yield better oxygen barrier
(Sothornvit and Krochta, 2000b). WPHs made good films with oxygen permeability and water vapor transmission rate values similar, but with more flexibility, than WPI films at the same glycerol content (Schmid, 2013; Sothornvit and Krochta, 2000a). Increasing the WPH content leads to a decrease in the molecular weight, in WPI-based films, and also significantly increases film flexibility, compared to films entirely produced from WPHs (Schmid et al., 2013). 


\section{Interfacial properties}

\section{Emulsification}

WPCs are used to improve emulsification in infant formula, meal replacement beverages, soups, gravies, and coffee whiteners (Gauthier et al., 1993). Food emulsions of the oil-in-water type are often stabilized by proteins. Temperature, $\mathrm{pH}$, ionic strength, protein concentration, protein to oil ratio, and oil volume fraction are among the major parameters that affect the physical properties of the emulsion (Guzey and McClements, 2006).

Limited enzymatic hydrolysis was found to be successful in improving interfacial properties (both foaming and emulsification properties) of WPCs (Foegeding et al., 2002; Kilara and Panyam, 2003). Emulsification can be improved through controlled heat denaturation. As the WP unfolds, hydrophobic amino acid residues are exposed, which enhance the ability of the protein to orient at the oil/water interface. Extensive hydrolyzed WPHs can be used as emulsifiers with proper homogenization conditions and careful selection of concentrations (Agboola et al., 1998). The emulsion stability can also be improved by addition of polysaccharides in to the WPHs media (Ye et al., 2004). The interactions between charged polysaccharides and proteins can be used to improve the thickness of the surface layer or to create multi layers of surface (Decher, 1997). The tryptic hydrolysates are reported to be more active on surface and have more emulsification properties than the chymotryptic hydrolysates (Turgeon et al., 1991).

\section{Fat binding and whipping formation}

WP also has emulsifying properties allowing fat globules to be structural elements in heat induced WP gels. These emulsifications properties have led to the development of new cheese, meat, and confectionary products (de Wit, 1998). Approximately $5-10 \%$ of WP is BSA, the smallest protein component of whey and BSA has valuable fat binding properties (Francis and Wiley, 2000). Increased fat binding capacity was associated with an increase in hydrophobicity of the protein (Voutsinas and Nakai, 1983).

\section{Foaming and aeration}

Proteins stabilize foams by strongly adsorbing to the air-water interfaces, forming viscoelastic adsorbed layers and leading to a protein network with high viscosity (Rullier et al., 2010). Foaming properties are best when the WPs are undenatured, not competing with other surfactants at the air/water interface, and stabilized by an inc- rease in viscosity when foam formation occurs. Defatted WPCs can be used as egg substitutes to induce and stabilize foams in aerated food products such as meringues and Madeira-type cakes (de Wit, 1998). Innocente et al. (1998) reported that proteose peptone 3, a component that results from the milk fat globule membrane protein, has good foaming properties. At proteose peptone 3 concentrations of $0.05,0.10$, and $0.20 \mathrm{~g} / 100 \mathrm{~mL}$, equilibrium surface tensions at the air-water interface were reported to be $44.75,36.14$, and $32.11 \mathrm{mN} / \mathrm{m}$, respectively. Zhu and Damodaran (1994) suggested that the addition of proteose peptone sharply decreased the foam stability of WPI but did not affect the foam capacity.

Compared to intact WPs, limited enzymatic hydrolysis promotes foaming and aeration through more rapid absorption at the interface by reducing the peptide size (van der Ven et al., 2002). In WPH-35, Alcalase 2.4L resulted in the highest foaming expansion capacity of $287.5 \%$ after $5 \mathrm{~h}$ hydrolysis with $9.5 \% \mathrm{DH}$ compared to trypsin, pepsin, protease $\mathrm{A}$, and protease $\mathrm{M}$ hydrolysates (Jeewanthi et al., 2014). Davis et al. (2005) also reported on the superior forming ability of Alcalase $2.4 \mathrm{~L}$ and pepsin hydrolysates of $\beta-\mathrm{Lg}$ compared to trypsin. They declared native $\beta$ - Lg is resistant to hydrolysis by pepsin, which has a broad specificity with a preference for cleaving after hydrophobic residues. In WPH-30, the highest foaming ability has reported by flavourzyme enzyme (Yoon et al., 2010). Excessive hydrolyzed WPHs were showed poor foaming stability due to very short peptides production (Kilara and Panyam, 2003; Ye and Sing, 2006). van der Ven et al. (2002) declared that large molecular fractions than $7 \mathrm{kDa}$ has the highest foam stability compared to 44 hydrolysates of WPs. Interfacial films used to stabilize emulsions and foams also have designed from WPHs (Foegeding et al., 2002).

\section{Sensorial properties}

\section{Color, flavor, and texture}

The flavor profile for whey products ranges from a sweet/dairy (sweet whey) flavor, to virtually no (WPCs, WPIs) perceivable flavor (Keaton, 1999). Acid whey is used in dairy products such as in cheese powders, sauces, and sherbets where a tangy flavor is desired (Kosikowski, 1979). In the bakery industry, acid whey is used in bread, biscuits, and crackers for the gold surface color it provides (Kosikowski, 1979). Color found in whey may result from naturally occurring xanthophylls, Maillard reaction products, and annatto addition (Smith, 2004). Another 
added benefit of WPC is that it can improve mouth feel of foods by creating a richer, fuller flavor. This can be especially important when formulating reduced-fat or low-fat meat products where some of the flavor contributed by fat is lost. The incorporation of WPC can be an economic alternative to other high priced flavor enhancing additives (Prabhu, 2006). Baking time and temperatures may require adjustment because crust color might develop more rapidly with whey-based ingredients. WPC $34-80 \%$ have been found to improve the color, thickness, and chewiness of full fat and low fat cookie formulations. WPIs has identified as an anti-browning agent that able to suppress enzymatic browning effect which reduce the brown color in apple juice and fresh cut apples (Perez-Gago et al., 2006; Yi and Ding, 2014). Also, some of the benefits recognized by consumers include good crust color developed through the Maillard browning reaction while using high temperature in food. WPCs are also bland tasting and contribute no foreign or off-flavors when used as ingredients (Burrington, 1999). Aldehydes including hexanal, have been suggested as the compounds responsible for off-flavors in liquid and dried whey products (Tomaino et al., 2004; Wright et al., 2009). Concentrations increased with storage time concurrent with increased off-flavors (Wright et al., 2009). Off-flavors in whey products can carry into ingredient applications and negatively affect consumer acceptance (Drake et al., 2009; Wright et al., 2009).

A major disadvantage of protein hydrolysis is the release of bitter-tasting peptides that limits the use of WPHs to low concentrations at which bitterness is not detected (Sinha et al., 2007). Rios et al. (2004) have mentioned that limiting the hydrolysis to less than $8 \%$ is a better option to minimize the bitter peptides. Small hydrophobic peptides and non-protein nitrogen released during the enzymatic hydrolysis are the major contributors to the bitter taste (Adler-Nissen, 1986; Matoba and Hata, 1972). Hydrophobic amino acids were bitterer when both the $\alpha$ amino and carboxyl groups were involved in peptide bond formation than when the bond formation occurred at the $\mathrm{N}-$ or C-terminus of peptides (Matoba and Hata, 1972). WPHs produced with Alcalase $2.4 \mathrm{~L}$ were bitterer than hydrolysates generated with Prolyve or Corolase, under similar reaction parameters (Spellman et al., 2009). On the other hand, free amino acids are also converted to flavorful compounds by heat and chemical interaction with other compounds. When WPs are enzymatically hydrolyzed, they develop flavor enhancing properties. WPHs can refine, brighten, accentuate, and naturally enhance key flavor notes in soups, sauces, dips, and meat products (Prabhu, 2006). WPHs have the tendency to bind a variety of flavor chemicals. As a flavor enhancer, WPH addition to liquid whey and further production to spray dried WPC successfully led to a decrease in cardboard flavor and short chain aldehyde concentration compared to the control liquid whey and WPCs. WPH has its own distinct flavor and aroma as well (Drake et al., 2009).

\section{Conclusion}

WP products are used in food applications considering their functional benefits over the other proteins in the industry. The major functional activities of the protein depend on their hydration, gelation, interfacial, aggregation, and sensorial properties. These properties are better enhanced via enzymatic hydrolysis than via chemical or technical means. WPHs enhance functionality due to their ability to expose the globular protein structure, reduce the average molecular weight and, increase the ionic strength, molecular charges, and protein-to-protein interactions, properties which are lacking in non-hydrolyzed WPCs and WPIs. Moreover, the enzymatic hydrolysis avoids the heat denaturation of proteins and maintains the functionality through the food production process. The optimum functional ability of WPHs would be achieved by using proper homogenization conditions, hydrolysis conditions (enzyme-to-substrate ratio, temperature, $\mathrm{pH}$, and time), the type of enzyme, and environmental conditions in food industry.

\section{Acknowledgements}

This work was supported by Priority Research Centers Program through the National Research Foundation of Korea (NRF) funded by the Ministry of Education, Science and Technology (2009-0093824).

\section{References}

1. Adler-Nissen, J. (1986) A Review of Food Protein Hydrolysis Specific Areas. In: Enzymatic hydrolysis of food proteins, Elsevier, London, England, pp. 57-109.

2. Agboola, S. O., Singh, H., Munro, P., Dalglesh, D. G., and Singh, A. M. (1998) Destabilization of oil-in-water emulsions formed using highly hydrolysed whey proteins. J. Agric. Food Chem. 46, 84-90.

3. Athira, S., Mann, B., Saini, P., Sharma, R., Kumar, R., and Singh, A. K. (2014) Production and characterisation of whey protein hydrolysates having antioxidant activity from cheese 
whey. J. Sci. Food Agri. DOI 10.1002/jsfa.7032.

4. Barbut, S. (2007) Effect of hydrolyzed and regular dairy proteins on the texture, colour and microstructure of poultry meat emulsions. Br. Poult. Sci. 48, 655-660.

5. Bouaouina, H., Desrumaux, A., Loisel, C., and Legrand, J. (2006) Functional properties of whey proteins as affected by dynamic high pressure treatment. Int. Dairy J. 16, 275-284.

6. Bryant, C. and McClements, D. J. (1998) Molecular basis of cold-setting whey protein ingredients. Trends Food Sci. Technol. 9, 143-151.

7. Burrington, K. (1999) Whey products in baked goods applications monograph - Bakery. U.S. Dairy Export Council. USA. eA2.1- eA2.8.

8. Creusot, N. and Gruppen, H. (2007a) Enzyme-induced aggregation and gelation of proteins. Biotech. Adv. 25, 597-601.

9. Creusot, N. and Gruppen, H. (2007b) Protein peptide interactions in mixtures of whey peptides and whey proteins. J. Agric. Food Chem. 55, 2474-2481.

10. Creusot, N. and Gruppen, H. (2008) Hydrolysis of whey protein isolate with Bacillus licheniformis protease: Aggregating capacities of peptide fractions. J. Agric. Food Chem. 56, 10332-10339.

11. Creusot, N., Gruppen, H., Van Koningsveld, G. A., De Kruif, C. G., and Vorgen, A. G. J. (2006) Peptide-peptide and protein-peptide interactions in mixtures of whey protein isolate and whey protein isolate hydrolysates. Int. Dairy J. 16, 840849.

12. Davis, J. P., Doucet, D., and Foegeding, E. A. (2005) Foaming and interfacial properties of hydrolyzed $\beta$-lactoglobulin. J. Colloid Interface Sci. 288, 412-422.

13. de Wit, J. N. (1998) Nutritional and functional characteristics of whey protein in food products. J. Dairy Sci. 81, 597-608.

14. Decher, G. (1997) Fuzzy nanoassemblies: Toward layered polymeric multi-composites. Science 277, 1232-1237.

15. Doucet, D. and Foegeding, E. A. (2005) Gel formation of peptides produced by extensive enzymatic hydrolysis of $\beta$ lactoglobulin. Biomacromolecules 6, 1140-1148.

16. Doucet, D., Gauthier, S. F., and Foegeding, E. A. (2001) Rheological characterization of a gel formed during extensive enzymatic hydrolysis. J. Food Sci. 66, 711-715.

17. Doucet, D., Gauthier, S. F., Otter, D. E., and Foegeding, E. A. (2003a) Enzyme-induced gelation of extensively hydrolyzed whey proteins by alcalase: Comparison with the plastein reaction and characterization interactions. J. Agric. Food Chem. 51, 6036-6042.

18. Doucet, D., Otter, D. E., Gauthier, S. F., and Foegeding, E. A. (2003b) Enzyme-induced gelation of extensively hydrolyzed whey proteins by alcalase: Peptide identification and determination of enzyme specificity. J. Agric. Food Chem. 51, 6300-6308.

19. Drake, M. A., Miracle, R. E., and Wright, J. M. (2009) Sensory Properties of Dairy Proteins. In: Milk proteins from expression to food. Thompson, A., Boland, M., and Singh, H. (eds) Elsevier, Amsterdam, The Netherlands. pp. 429-448.

20. Flanagan, J. and FitzGerald, R. J. (2002) Physicochemical and nitrogen solubility properties of Bacillus proteinase hydroly- sates of sodium caseinate incubated with transglutaminase preand post-hydrolysis. J. Agric. Food Chem. 50, 5429-5436.

21. Foegeding, E. A., Davis, J. P., Doucet, D., and McGuffey, M. K. (2002) Advances in modifying and understanding whey protein functionally. Trends Food Sci. Tech.13, 151-159.

22. Francis, F. J. and Wiley R. H. (2000) Whey: Composition, Properties, Processing and Uses. In: Wiley encyclopedia of food science and technology. 2nd Edition. New York, NY. pp. 2652-2661.

23. Gauthier, S. F., Paquin, P., Pouliot, Y., and Turgeon, S. (1993) Surface activity and related functional properties of peptides obtained from whey proteins. J. Dairy Sci. 76, 321328.

24. Goode, K. R., Bowen, J., Akhtar, N., Robbins, P. T., and Fryer, P. J. (2013) The effect of temperature on adhesion forces between surfaces and model foods containing whey protein and sugar. J. Food Eng. 118, 371-379.

25. Groleau, P. E., Gauthier, S. F., and Pouliot, Y. (2003a) Effect of residual chymotryptic activity in a trypsin preparation on peptide aggregation in a $\beta$-lactoglobulin hydrolysate. Int. Dairy J. 13, 887-895.

26. Groleau, P. E., Morin, P., Gauthier, S. F., and Pouliot, Y. (2003b) Effect of physicochemical conditions on peptide-peptide interactions in a tryptic hydrolysate of $\beta$-lactoglobulin and intensification of aggregating peptides. J. Agric. Food Chem. 51, 4370-4375.

27. Guzey, D. and McClements, D. J. (2006) Formation, stability and properties of multilayer emulsions for application in the food industry. Adv. Colloid Interface Sci. 128, 227-248.

28. Huang, X. L., Catignani, G. L., and Swaisgood, H. E. (1999) Modication of rheological properties of whey protein isolates by limited proteolysis. Nahrung 43, 79-85.

29. Innocente, N., Corradini, C., Blecker, C., and Paquot, M. (1998) Dynamic surface tension properties of the proteosepeptone fraction of bovine milk. J. Dairy Sci. 81, 1833-1839.

30. Ipsen, R., Otte, J., Lomholt, S. T., and Qvist, K. B. (2000) Standardized reaction times used to describe the mechanism of enzyme-induced gelation in whey protein systems. J. Dairy Res. 67, 403-413.

31. Ipsen, R., Otte, J., and Schumacher, E. (1997) Controlled stress rheometry compared with Formagraph measurements for characterization of the enzyme induced gelation of whey proteins at various pH. Ann. Trans. Nordic Rheology Society 5, 48-50.

32. Jeewanthi, R. K. C., Paik, H. D., Kim, M. H., Lee, N. K., Kim, S. Y., and Yoon, Y. C. (2014) Characteristics of whey protein hydrolysates from cheese whey, favors on various food applications. Chem. Ind. Chem. Eng. Q. 20, 503-509.

33. Ju, Z. Y. and Kilara, A. (1998) Gelation of pH-aggregated whey protein isolate solution induced by heat, protease, calcium salt, and acidulant. J. Agric. Food Chem. 46, 1830-1835.

34. Ju, Z. Y., Otte, J., Madsen, J. S., and Qvist, K. B. (1995) Effects of limited proteolysis on gelation and gel properties of whey protein isolate. J. Dairy Sci. 78, 2119-2128.

35. Kang, I. J., Matsumura, Y., Ikura, K., Motoki, M., Sakamoto, H., and Mori, T. (1994) Gelation and gel properties of soybean 
glycinin in a transglutaminase-catalyzed system. J. Agric. Food Chem. 42, 159-165.

36. Keaton, J. (1999) Whey protein and lactose products in processed meats, Applications monograph - Meat, Published by U.S. Dairy Export Council, eD2.1-eD2.8.

37. Kilara, A. and Panyam, D. (2003) Peptides from milk proteins and their properties. Crit. Rev. Food Sci. Nutr. 43, 607-633.

38. Kim, S. B., Seo, I. S., Khan, M. A., Ki, K. S., Lee, W. S., Lee, H. J., Shin, H. S., and Kim, H. S. (2007) Enzymatic hydrolysis of heated whey: Iron-binding ability of peptides and antigenic protein fractions. J. Dairy Sci. 90, 4033-4042.

39. Konrad, G., Kleinschmidt, T., Rohenkohl, H., and Reimerdes, E. H. (2005) Peptic partial hydrolysis of whey protein concentrate for modifying the surface properties of whey protein. II. Effects on the emulsifying and foaming properties. Milchwissenschaft 60, 195-198.

40. Kosikowski, F. V. (1979) Whey utilization and whey products. J. Dairy Sci. 62, 1149-1160.

41. Kresic, G. and Lelas, V. Herceg, Z., and Rezek, A. (2006) Effects of high pressure on functionality of whey protein concentrate and whey protein isolate. Lait 86, 303-315.

42. Kumar, S. K., Jayaprakasha, Manjappa H., Paik, H. D., Kim, S. K., Han, S. E., Jeong, A. R., and Yoon, Y. C. (2010) Production of ready-to-reconstitute functional beverages by utilizing whey protein hydrolysates and probiotics. Korean $J$. Food Sci. An. 30, 575-578.

43. Madsen, J. S., Ahmt, T. O., Otte, J., Halkier, T., and Qvist, K. B. (1997) Hydrolysis of $\beta$-lactoglobulin by four different proteinases monitored by capillary electrophoresis and high performance liquid chromatography. Int. Dairy J. 7, 399-409.

44. Mahmoud, M. I. (1994) Physicochemical and functional, properties of protein hydrolysates in nutritional products. Food Technol. 48, 89-95.

45. Majhi, P. R., Ganta, R. R., Vanam, R. P., Seyrek, E., Giger, K., and Dubin, P. L. (2006) Electrostatically driven protein aggregation: $\beta$-lactoglobulin at low ionic strength. Langmuir 22, 9150-9159.

46. Mann, E. J. (2000) Whey products and their uses. Dairy Ind. Int. 65, 13-14.

47. Mate, J. I. and Krochta, J. M. (1996) Comparison of oxygen and water vapor permeabilities of whey protein isolate and $\beta$ lactoglobulin edible films. J. Agric. Food Chem. 44, 30013004.

48. Matoba, T. and Hata, T. (1972) Relationship between bitterness of peptides and their chemical structures. Agric. Biol. Chem. 36, 1423-1431.

49. McHugh, T. H. and Krochta, J. M. (1994) Sorbitol-plasticized vs. glycerol-plasticized whey-protein edible films: Integrated oxygen permeability and tensile property evaluation. J. Agric. Food Chem. 42, 841-845.

50. Mehalebi, S., Nicolai, T., and Durand, D. (2008) Light scattering study of heat-denatured globular protein aggregates. Int. J. Biol. Macromol. 43, 129-135.

51. Miller, K. S., Chiang, M. T., and Krochta, J. M. (1997) Heat curing of edible whey protein films. J. Food Sci. 62, 11891193.
52. Morr, C. V. and Ha, E. Y. (1993) Whey protein concentrates and isolates: Processing and functional properties. Crit. Rev. Food Sci. Nutr. 33, 431-476.

53. Mutilangi, W. A. M., Panyam, D., and Kilara, A. (1996) Functional properties of hydrolysates from proteolysis of heatdenatured whey protein isolate. J. Food Sci. 61, 270-275.

54. Nakamura, T., Sado, H., Syukunobe, Y., and Hirata, T. (1993) Antigenicity of whey protein hydrolysates prepared by combination of two proteinases. Milchwissenschaft 48, 667-670.

55. Otte, J., Ju, Z. Y., Faergemand, M., Lomholt, S. B., and Qvist, K. B. (1996a) Protease-induced aggregation and gelation of whey proteins. J. Food Sci. 61, 911-923.

56. Otte, J., Ju, Z. Y., Skriver, A., and Qvist, K. B. (1996b) Effect of limited proteolysis on the microstructure of heat-induced whey protein gels at varying pH. J. Dairy Sci. 79, 782-790.

57. Otte, J., Schumacher, E., Ipsen, R., Ju, Z. Y., and Qvist, K. B. (1999) Protease-induced gelation of unheated and heated whey proteins: Effect of $\mathrm{pH}$, temperature and concentrations of protein, enzyme and salts. Int. Dairy J. 9, 801-812.

58. Pelegrine, D. H. G. and Gasparetto, C. A. (2005) Whey proteins solubility as function of temperature and $\mathrm{pH}$. LWTFood Sci. Technol. 38, 77-80.

59. Pelegrine, D. H. G. and Gomes, M. T. M. S. (2012) Analysis of whey proteins solubility at high temperatures. Int. J. Food Eng. 3, 1556-3758.

60. Perea, A., Ugalde, U., Rodriguez, I., and Serra, J. L. (1993) Preparation and characterization of whey protein hydrolysates: Applications in industrial whey bioconversion processes. Enzyme Microb. Technol. 15, 418-423.

61. Perez-Gago, M. B. and Krochta, J. M. (2002) Formation and Properties of Whey Protein Films and Coatings. In: Proteinbased films and coatings. Gennadios, A. (ed) CRC Press, Boca Raton, FL. pp.159-180.

62. Perez-Gago, M. B., Serra, M., and Del Río, M. A. (2006) Color change of fresh-cut apples coated with whey protein concentrate-based edible coatings. Postharvest Biol. Technol. 39, 84-92.

63. Pinterits, A. and Arnteld, S. D. (2007) The effect of limited proteolysis on canola protein gelation. Food Chem. 102, 13371343.

64. Pouliot, Y., Guy, M. M., Tremblay, M., Gaonac'h, A. C., Ting, B. P. C. P., Gauthier, S. F., and Voyer, N. (2009) Isolation and characterization of an aggregating peptide from a tryptic hydrolysate of whey proteins. J. Agric. Food Chem. 57, 37603764.

65. Prabhu, G. (2006) U.S. Whey protein in processed meats. Application monograph processed meats, U.S. Dairy Export Council. e-3-6-1- e-3-6-12.

66. Rabiey, L. and Britten, M. (2009a) Effect of protein composition on the rheological properties acid-induced whey protein gels. Food Hydrocolloids 23, 973-979.

67. Rabiey, L. and Britten, M. (2009b) Effect of whey protein enzymatic hydrolysis on the rheological properties acid-of acid induced whey protein gels. Food Hydrocolloids 23, 23022308.

68. Rinn, J. C., Morr, C. V., Seo, A., and Surak, J. G. (1990) Eva- 
luation of nine semi-pilot scale whey protein pre-treatment modifications for providing whey protein concentrates. $J$. Food Sci. 55, 510-515.

69. Rios, G. M., Belleville, M. P., Paolucci, D., and Sanchez, J. (2004) Progress in enzymatic membrane reactors: A review. J. Membr. Sci. 242, 189-196.

70. Rocha, C., Teixeria, J. A., Hilliou, L., Sampaio, P., and Goncalves, M. P. (2009) Rheological and structural characterization of gels from whey protein hydrolysates/locust bean gum mixed systems. Food Hydrocolloids 23, 1734-1745.

71. Rullier, B., Axelos, M. A. V., Langevin, D., and Novales, B. (2010) $\beta$-lactoglobulin aggregates in foam films: Effect of the concentration and size of the protein aggregates. J. Colloid Interface Sci. 343, 330-337.

72. Schmid, M. (2013) Properties of cast films made from different ratios of whey protein isolate, hydrolysed whey protein isolate and glycerol, Materials 6, 3254-3269.

73. Schmid, M., Hinz, L. V., Wild, F., and Noller, K. (2013) Effects of hydrolysed whey proteins on the techno-functional characteristics of whey protein-based films. Materials 6, 927940.

74. Schmitt, C., Bovay, C., Vuilliomenet, A., Rouvet, M., Bovetto, L., Barbar, R., and Sanchez, C. (2009) Multi-scale characterization of individualized $\beta$-lactoglobulin micro gels formed upon heat treatment under narrow $\mathrm{pH}$ range conditions. Langmuir 25, 7899-7909.

75. Sharma, S., Singh, R., and Rana, S. (2011) Bioactive peptides: Review, Int. J. Bioautomation 15, 223-250.

76. Sinha, R., Radha, C., Prakash, J., and Kaul, P. (2007) Whey protein hydrolysate: Functional properties, nutritional quality and utilization in beverage formulation. Food Chem. 101, 1484-1491.

77. Smith, K. (2004) Whey processing CDR technical review: Bleaching. Wisconsin Center for Dairy Research, Madison. pp. 1-17.

78. Smithers, G. W. (2008) Whey and whey proteins-from 'gutter-to-gold'. Int. Dairy J. 18, 695-704.

79. Sothornvit, R. and Krochta, J. M. (2000a) Oxygen permeability and mechanical properties of films from hydrolyzed whey protein. J. Agric. Food Chem. 48, 3913-3916.

80. Sothornvit, R. and Krochta, J. M. (2000b) Water vapor permeability and solubility of films from hydrolyzed whey protein. J. Food Sci. 65, 700-703.

81. Sousa, J. R. R., Lopes, G. P., Tardioli, P. W., Giordano, R. L. C., Almeida, P. I. F., and Giordano, R. C. (2004) Kinetic model for whey protein hydrolysis by alcalase multipoint-immobilized on agarose gel particles. Braz. J. Chem. Eng. 21, 147-153.

82. Spellman, D., Kenny, P., O'Cuinn, G., and FitzGerald, R. J.
(2005) Aggregation properties of whey protein hydrolysates generated with Bacillus licheniformis proteinase activities. $J$. Agric. Food Chem. 5, 1258-1265.

83. Spellman, D., O'Cuinn, G., and FitzGerald, R. J. (2009) Bitterness in Bacillus proteinase hydrolysates of whey proteins. Food Chem.114, 440-446.

84. Suarez, E., San Martin, F., Alvarez, R., and Coca, J. (1992) Reverse osmosis of whey. Determination of mass transfer coefficients. J. Membr. Sci. 68, 301-305.

85. Tomaino, R. M., Turner, L. G., and Larick, D. K. (2004) The effect of Lactococcus lactis starter cultures on the oxidative stability of liquid whey. J. Dairy Sci. 87, 300-307.

86. Tsai, S. J., Unklesbay, N., Unklesbay, K., and Clarke, A. (1998) Water and absorption properties of restructured beef products with five binders at four isothermal temperatures. $L W T$ Food Sci. Technol. 31, 78-83.

87. Turgeon, S. L., Gauthier, S. F., and Paquin, P. (1991) Interfacial and emulsifying properties of whey fractions obtained with a two-step ultrafiltration process. J. Agric. Food Chem. 39, 673-676.

88. van der Ven, C., Gruppen, H., De Bont, D. B. A., and Voragen, A. G. J. (2002) Correlations between biochemical characteristics and foam-forming and stabilizing ability of whey and casein hydrolysates. J. Agric. Food Chem. 50, 2938-2946.

89. Voutsinas, L. P. and Nakai, S. (1983) A simple turbidimetric method for determining the fat binding capacity of proteins. J. Agric. Food Chem. 31, 58-59.

90. Wright, B. J., Zevchak, S. E., Wright, J. M., and Drake, M. A. (2009) The impact of agglomeration and storage on flavor and flavor stability of whey protein $80 \%$ and whey protein isolate. J. Food Sci. 74, 17-29.

91. Ye, A., Hemar, Y., and Singh, H. (2004) Flocculation and coalescence of droplets in oil-in-water emulsions formed with highly hydrolysed whey proteins as influenced by starch. Colloid. Surface. B. 38, 1-9.

92. Ye, A. and Singh, H. (2006) Heat stability of oil-in-water emulsions formed with intact or hydrolysed whey proteins: Influence of polysaccharides. Food Hydrocolloids 20, 269276.

93. Yi, J. and Ding, Y. (2014) Dual effects of whey protein isolates on the inhibition of enzymatic browning and clarification of apple juice. Czech J. Food Sci. 32, 601-609.

94. Yoon, Y. C., An, S. I., Jeong, A. R., Han, S. E., Kim, M. H., and Lee, C. K. (2010) Characteristics of whey protein (WPC30) hydrolysates from cheese whey. J. Animal Sci. Tech. 52, 435-440.

95. Zhu, H. and Damodaran, S. (1994) Proteose-peptones and physical factors affect foaming properties of whey protein isolate. J. Food Sci. 59, 554-560. 